DOI $10.31489 / 2021 \mathrm{M} 2 / 62-66$

MSC 54E15, 54D20

\author{
B.E. Kanetov ${ }^{1, *}$, A.M. Baidzhuranova ${ }^{2}$ \\ ${ }^{1}$ Jusup Balasagyn Kyrgyz National University, Bishkek, Kyrgyzstan; \\ ${ }^{2}$ Institute of Mathematics of National Academy of Sciences of Kyrgyz Republic, Bishkek, Kyrgyzstan \\ (E-mail: bekbolot_kanetov@mail.ru, anara1403@bk.ru)
}

\title{
Paracompact-type mappings
}

\begin{abstract}
Recently a new direction of uniform topology called the uniform topology of uniformly continuous mappings has begun to develop intensively. This direction is devoted, first of all, to the extension to uniformly continuous mappings of the basic concepts and statements concerning uniform spaces. In this case a uniform space is understood as the simplest uniformly continuous mapping of this uniform space into a one-point space. The investigations carried out have revealed large uniform analogs of continuous mappings and made it possible to transfer to uniformly continuous mappings many of the main statements of the uniform topology of spaces. The method of transferring results from spaces to mappings makes it possible to generalize many results. Therefore, the problem of extending some concepts and statements concerning uniform spaces to uniformly continuous mappings is urgent. In this article, we introduce and study uniformly $R$-paracompact, strongly uniformly $R$-paracompact, and uniformly $R$-superparacompact mappings. In particular, we solve the problem of preserving $R$-paracompact (respectively, strongly uniformly $R$-paracompact, uniformly $R$-superparacompact) spaces towards the preimage under uniformly $R$-paracompact (respectively, strongly uniformly $R$-paracompact, uniformly $R$-superparacompact) mappings.
\end{abstract}

Keywords: uniformly continuous mapping, uniformly locally finite open cover, uniformly star finite open cover, uniformly finite-component open cover.

\section{Introduction}

The most important properties of the paracompact-types are paracompact, strongly paracompact, and superparacompact spaces in General Topology. One of the interesting problems of Uniform Topology is extending the basic properties of uniform spaces to mappings.

For coverings $\alpha$ and $\beta$ of the set $X$, the symbol $\alpha \succ \beta$ means that the covering $\alpha$ is a refinement of the covering $\beta$, i.e., for any $A \in \alpha$ there exists $B \in \beta$ such that $A \subset B$. For coverings $\alpha, \beta$ of a set $X$ and $x \in X, M \subset X$ we have: $\alpha \wedge \beta=\{A \cap B: A \in \alpha, B \in \beta\}, \alpha(x)=\bigcup \operatorname{St}(\alpha, x), \operatorname{St}(\alpha, x)=\{A \in \alpha: A$ э $x\}$, $\alpha(M)=\bigcup S t(\alpha, M), S t(\alpha, M)=\{A \in \alpha: A \bigcap M \neq \varnothing\}$.

A topological space $X$ is called paracompact if every open cover $\alpha$ has a locally finite open refinement [1]. A topological space $X$ is called strongly paracompact if every open cover $\alpha$ has a star finite open refinement [1]. A topological space $X$ is called superparacompact if every open cover $\alpha$ has a finite-component open refinement [2]. A uniform space $(X, U)$ called uniformly $R$-paracompact if every open covering has a uniformly locally finite open refinement [3]. A uniform space $(X, U)$ called strongly uniformly $R$-paracompact if every open covering has a uniformly star finite open refinement [2]. A uniform space $(X, U)$ called uniformly $R$-superparacompact if every open covering has a uniformly finite-component open refinement [2].

Let $f:(X, \tau) \rightarrow(Y, \eta)$ be a continuous mapping of topological space $(X, \tau)$ to a topological space $(Y, \eta)$. A mapping $f:(X, \tau) \rightarrow(Y, \eta)$ is called a paracompact (strongly paracompact, superparacompact) mappings if for each open covering $\alpha$ of $(X, \tau)$ there exist a open covering $\beta$ of $(Y, \eta)$ and locally finite (star finite, finite component) open covering $\gamma$ of $(Y, \eta)$ such that $f^{-1} \beta \wedge \gamma \succ \alpha[4]$.

Throughout this article by a uniformity we understand a uniformity defined with help of covers, for the uniformity $U$ by $\tau_{U}$ we understand the topology generated by this uniformity, for the Tychonoff space $X$ by $U_{X}$ we understand a universal uniformity, all uniform spaces are assumed to be Hausdorff and mappings are uniformly continuous.

\footnotetext{
${ }^{*}$ Corresponding author.
}

E-mail: kanetov@mail.ru 


\section{Uniformly R-paracompact, strongly uniformly R-paracompact and uniformly $R$-superparacompact mappings} $(Y, V)$.

Let $f:(X, U) \rightarrow(Y, V)$ be a uniformly continuous mapping of a uniform space $(X, U)$ to a uniform space

Definition 1. A uniformly continuous mapping $f:(X, U) \rightarrow(Y, V)$ of a uniform space $(X, U)$ to a uniform space $(Y, V)$ is called

$\left(P_{1}\right)$ uniformly $R$-paracompact,

$\left(P_{2}\right)$ strongly uniformly $R$-paracompact,

$\left(P_{3}\right)$ uniformly $R$-superparacompact

mapping if for any open covering $\alpha$ of the uniform space $(X, U)$ there exist such open covering $\beta$ of the uniform space $(Y, V)$ and

$\left(p_{1}\right)$ uniformly locally finite

$\left(p_{2}\right)$ uniformly star finite

$\left(p_{3}\right)$ uniformly finite-component

an open covering $\gamma$ of a space $(X, U)$ such that $f^{-1} \beta \wedge \gamma \succ \alpha$.

Proposition 1. Let $f:(X, U) \rightarrow(Y, V)$ be a uniformly continuous mapping. If $(X, U)$ is a uniformly $R$-paracompact (strongly uniformly $R$-paracompact, uniformly $R$-superparacompact) space, then the mapping $f$ is a uniformly $R$-paracompact (strongly uniformly $R$-paracompact, uniformly $R$-superparacompact) mapping.

Proof. Let $f:(X, U) \rightarrow(Y, V)$ be a uniformly continuous mapping of a uniformly $R$-paracompact (strongly uniformly $R$-paracompact, uniformly $R$-superparacompact) uniform space $(X, U)$ to a uniform space $(Y, V)$ and $\alpha$ be an arbitrary open covering of the space $(X, U)$. Then there exists a uniformly locally finite (uniformly star finite, uniformly finite-component) open covering $\lambda$ of the space $(X, U)$ such that $\lambda \succ \alpha$. Let $\beta$ be an arbitrary open covering of the space $(Y, V)$. Then, $f^{-1} \beta$ is an open covering of the space $(X, U)$. It is clear that $f^{-1} \beta \wedge \lambda \succ \alpha$. Therefore, the mapping $f$ is a uniformly $R$-paracompact (strongly uniformly $R$-paracompact, uniformly $R$-superparacompact) mapping.

Proposition 2. If $f:(X, U) \rightarrow(Y, V)$ is a uniformly $R$-paracompact (strongly uniformly $R$-paracompact, uniformly $R$-superparacompact) mapping and $Y=\{y\}$, then the uniform space $(X, U)$ is a uniformly $R$-paracompact (strongly uniformly $R$-paracompact, uniformly $R$-superparacompact) space.

Proof. Let $\alpha$ be an arbitrary open covering of the space $(X, U)$. Then there exist an open covering $\beta$ of a space $(Y, V)$ and a uniformly locally finite open covering $\gamma$ of a space $(X, U)$ such that $f^{-1} \beta \wedge \gamma \succ \alpha$. It is clear that $f^{-1} \beta \wedge \gamma=\gamma$. So, $(X, U)$ is a uniformly $R$-paracompact (strongly uniformly $R$-paracompact, uniformly $R$-superparacompact) space.

Lemma 1. If $\alpha$ and $\beta$ are the uniformly locally finite (uniformly star finite, uniformly finite-component) coverings of the space $(X, U)$, then $\alpha \wedge \beta$ is also a uniformly locally finite (uniformly star finite, uniformly finite-component) covering of the space $(X, U)$.

Proof. We carry out the proof for a uniformly locally finite case, and the rest of the cases proceed similarly. Let $\alpha, \beta$ be the uniformly locally finite coverings of a space $(X, U)$. Then there exist such uniform coverings $\lambda, \eta \in U$ that for any $L \in \lambda, E \in \eta$. We have $L \subset \bigcup_{i=1}^{n} A_{i}$ and $E \subset \bigcup_{j=1}^{k} B_{j}$, where $A_{i} \in \alpha, B_{j} \in \beta, i=1,2, \ldots, n$, $j=1,2, \ldots, k$. Hence, $L \cap E \subset\left(\bigcup_{i=1}^{n} A_{i}\right) \cap\left(\bigcup_{j=1}^{k} B_{k}\right) \subset \bigcup_{i=1}^{n} \bigcup_{j=1}^{k}\left(A_{i} \cap B_{j}\right)$. It is clear that $\lambda \wedge \eta$ is a uniform covering and $L \bigcap E \in \lambda \wedge \eta$. Note that each $L \bigcap M \in \lambda \wedge \eta$ meets with a finite number of elements of the covering $\alpha \wedge \beta$. Hence, $\alpha \wedge \beta$ is a uniformly locally finite covering of the space $(X, U)$.

Lemma 2. Let $f:(X, U) \rightarrow(Y, V)$ be a uniformly continuous mapping. If $\beta$ is a uniformly locally finite (uniformly star finite, uniformly finite-component) covering of a uniform space $(Y, V)$, then $f^{-1} \beta$ is a uniformly locally finite (uniformly star finite, uniformly finite-component) covering of a uniform space $(X, U)$.

Proof. We also carry out the proof for a uniformly locally finite case, and the rest of the cases can be proceeded similarly. Let $\beta$ be a uniformly locally finite covering of the space $(Y, V)$. Let us show that the covering $f^{-1} \beta$ is a uniformly locally finite covering of the space $(X, U)$. Since $\beta$ is a uniformly locally finite, there exists a uniform covering $\lambda \in V$ such that each element of which meets only with a finite number of elements of the covering $\beta$. For each $L \in \lambda$ there exist $B_{1}, B_{2}, \ldots, B_{n}$ from $\beta$ such that $L \subset \bigcup_{i=1}^{n} B_{i}$. Therefore, $f^{-1} L \subset f^{-1}\left(\bigcup_{i=1}^{n} B_{i}\right)=\bigcup_{i=1}^{n} f^{-1}\left(B_{i}\right)$, where $f^{-1}\left(B_{i}\right) \in \beta, i=1,2, \ldots, n$. It's clear that $f^{-1} \lambda \in U$. Then $f^{-1} \lambda$ is the required uniform covering. So, the covering $f^{-1} \beta$ is a uniformly locally finite covering of the space $(X, U)$. 
Proposition 3. A composition of two uniformly $R$-paracompact (strongly uniformly $R$-paracompact, uniformly $R$-superparacompact) mappings is again a uniformly $R$-paracompact (strongly uniformly paracompact, uniformly $R$-superparacompact) mapping.

Proof. Let $f:(X, U) \rightarrow(Y, V)$ and $g:(Y, V) \rightarrow(Z, W)$ be the uniformly $R$-paracompact (strongly uniformly $R$-paracompact, uniformly $R$-superparacompact) mappings. Let $\alpha$ be an arbitrary open covering of the space $(X, U)$. Then, there exist an open covering $\beta$ of a space $(Y, V)$ and a uniformly locally finite (uniformly star finite, uniformly finite-component) open covering $\gamma$ of a space $(X, U)$ such that $f^{-1} \beta \wedge \gamma \succ \alpha$. Due to the uniformly $R$-paracompactness (strongly uniformly $R$-paracompactness, uniformly $R$-superparacompactness) of the mapping $g$, for an open covering $\beta$ there exist such an open covering $\lambda$ of the space $(Z, W)$ and a uniformly locally finite (uniformly star finite, uniformly finite-component) open covering $\eta$ of the space $(Y, V$ ) that $g^{-1} \lambda \wedge \eta \succ \beta$.

Then, $(g \circ f)^{-1} \lambda \wedge\left(f^{-1} \eta \wedge \gamma\right) \succ f^{-1} \beta \wedge \gamma \succ \alpha$. Put $f^{-1} \eta \wedge \gamma=\mu$. According to Lemmas 1 and 2 , a covering $\mu$ is a uniformly locally finite (uniformly star finite, uniformly finite-component) open covering of a space $(X, U)$. Therefore, $g \circ f:(X, U) \rightarrow(Z, W)$ is a uniformly $R$-paracompact (strongly uniformly $R$-paracompact, uniformly $R$-superparacompact) mapping.

Proposition 4. Let $f:(X, U) \rightarrow(Y, V)$ be a uniformly continuous mapping of a uniform space $(X, U)$ to a uniform space $(Y, V)$ and $\left(M, U_{M}\right)$ be a closed subspace of a space $(X, U)$. If $f$ is a uniformly $R$-paracompact (strongly uniformly $R$-paracompact, uniformly $R$-superparacompact) mapping, then its restriction $\left.f\right|_{M}:\left(M, U_{M}\right) \rightarrow(Y, V)$ is also a uniformly $R$-paracompact (strongly uniformly $R$-paracompact, uniformly $R$-superparacompact) mapping.

Proof. Let $f:(X, U) \rightarrow(Y, V)$ be a uniformly $R$-paracompact (strongly uniformly $R$-paracompact, uniformly $R$-superparacompact) mapping and let $\left(M, U_{M}\right)$ be a closed subspace. Let $\alpha_{M}$ be an arbitrary open covering of the space $\left(M, U_{M}\right)$. Then there is an open covering $\alpha$ of a space $(X, U)$ such that $\alpha_{M}=\alpha \wedge\{M\}$. Let $\beta$ be an open covering of a space $(Y, V)$ and $\gamma$ is a uniformly locally finite (uniformly star finite, uniformly finite-component) open space $(X, U)$ such that $f^{-1} \beta \wedge \gamma \succ \alpha$. Then, $\left.f\right|_{M} ^{-1} \beta \wedge \gamma_{M} \succ \alpha_{M}$. Hence, the mapping $\left.f\right|_{M}:\left(M, U_{M}\right) \rightarrow(Y, V)$ is a uniformly $R$-paracompact (strongly uniformly $R$-paracompact, uniformly $R$-superparacompact) mapping.

Theorem 1. If the mapping $f$ and the space $(Y, V)$ are uniformly $R$-paracompact (strongly uniformly $R$-paracompact, uniformly $R$-superparacompact), then $(X, U)$ is $R$-paracompact (strongly uniformly $R$-paracompact, uniformly $R$-superparacompact).

Proof. Let $f$ and $(Y, V)$ be a uniformly $R$-paracompact (strongly uniformly $R$-paracompact, uniformly $R$-superparacompact) and $\alpha$ be an arbitrary open covering of the space $(X, U)$. Then, there are an open covering $\beta$ of a space $(Y, V)$ and a uniformly locally finite (uniformly star finite, uniformly finite-component) open covering $\gamma$ of a space $(X, U)$ such that $f^{-1} \beta \wedge \gamma \succ \alpha$. In the covering $\beta$ a refinement a uniformly locally finite (uniformly star finite, uniformly finite-component) open covering $\eta$ of a space $(Y, V)$. Then $f^{-1} \eta \wedge \gamma \succ \alpha$ and, according to Lemmas 1 and 2 , the covering $f^{-1} \eta \wedge \gamma$ is a uniformly locally finite (uniformly star finite, uniformly finitecomponent) covering. So, $(X, U)$ is a uniformly $R$-paracompact (strongly uniformly $R$-paracompact, uniformly $R$-superparacompact) space.

\section{References}

1 Энгелькинг Р. Общая топология / Р. Энгелькинг. - М., 1986.

2 Мусаев Д.К. Равномерно суперпаракомпактные, вполне паракомпактные и сильно паракомпактные равномерные пространства / Д.К. Мусаев // Докл. АН Республики Узбекистан. - 2004. - № 4. C. 3-9.

3 Rice M.D. A note on uniform paracompactness / M.D. Rice. // Proc. Amer. Math. Soc. - 1977. - 62. - No. 2. - P. 359-362.

4 Канетов Б.Э. Некоторые классы равномерных пространств и равномерно непрерывных отображений / Б.Э. Канетов. - Бишкек, 2013. 


\author{
Б.Э. Канетов ${ }^{1}$, А.М. Байджуранова ${ }^{2}$ \\ ${ }^{1}$ Жүсіп Баласавұн атындавы Қырзыз ұлттық, университеті, Бішкек, Қырғызстан; \\ ${ }^{2}$ Қырәыз Республикасы Ұлттық, вылым академиясынын, Математика институты, Бішкек, Қырвызстан
}

\title{
Паракомпактілі бейнелеудің түрлері
}

Кейінгі кездері бірқалыпты үздіксіз бейнелеулердің бірқалыпты топологиясы деп аталатын жаңа бағыт қарқынды дами бастады. Бұл бағыт, ең алдымен, бірқалыпты кеңістіктерге қатысты негізгі ұғымдар мен мәлімдемелерді бірқалыпты үзіліссіз бейнелеулерді таратуға арналған. Сонымен қатар, бірқалыпты кеңістік осы бірқалыпты кеңістікті бір нүктелі кеңістікке қарапайым бірқалыпты үзіліссіз бейнелеу ретінде түсініледі. Жүргізілген зерттеулер үзіліссіз бейнелеулердің үлкен, бірқалыпты аналогтарын анықтады және бірқалыпты кеңістік топологиясының көптеген негізгі тұжырымдарын бірқалыпты үзіліссіз бейнелеулерге өткізуге мүмкіндік берді. Нәтижелерді кеңістіктен бейнелеуге ауыстыру көптеген нәтижелерді қорытындылауға мүмкіндік береді. Сондықтан бірқалыпты кеңістіктерге қатысты кейбір ұғымдар мен мәлімдемелерді бірқалыпты үзіліссіз бейнелеулерге тарату есебі өзекті болып табылады. Осы жұмыста $R$-паракомпакт, қатты бірқалыпты $R$-паракомпакт және бірқалыпты $R$-суперпаракпакт бейнелері енгізіліп, зерттелді. Дербес жағдайда, $R$-паракомпакт (тиісінше, өте бірқалыпты $R$-паракомпакт, бірқалыпты $R$-суперпаракпакт) кеңістіктерін бейнеге қарай бірқалыпты $R$-паракомпакт (тиісінше, өте бірқалыпты $R$-паракомпакт, бірқалыпты $R$-суперпаракпакт) бейнелеулермен сақтау есебі шешіледі.

Kiлm сөздер: бірқалыпты үзіліссіз бейнелеу, бірқалыпты локалды ақырлы ашық жабын, бірқалыпты жұлдызды ақырлы ашық жабын, бірқалыпты ақырлы компонентті ашық жабын.

\author{
Б.Э. Канетов ${ }^{1}$, А.М. Байджуранова ${ }^{2}$ \\ ${ }^{1}$ Кыргызский национальный университет им. Жусупа Баласагына, Бишкек, Кыргызстан; \\ ${ }^{2}$ Институт математики Национальной академии наук Кыргызкой Республики, Бишкек, Кыргызстан
}

\section{Паракомпактные типы отображений}

В последнее время интенсивно развивается новое направление равномерной топологии - равномерная топология равномерно непрерывных отображений. Это направление посвящено, в первую очередь, распространению на равномерно непрерывные отображения основных понятий и утверждений, касающихся равномерных пространств. При этом равномерное пространство понимается как простейшее равномерно непрерывное отображение этого равномерного пространства в одноточечное пространство. Проведенные исследования выявили большие равномерные аналоги непрерывных отображений и позволили перенести на равномерно непрерывные отображения многие основные утверждения равномерной топологии пространств. Метод перенесения результатов с пространств на отображения позволяет обобщить многие результаты. Поэтому задача распространения некоторых понятий и утверждений, касающихся равномерных пространств, на равномерно непрерывные отображения является актуальной. В настоящей работе введены и исследованы равномерно $R$ паракомпактные, сильно равномерно $R$-паракомпактные и равномерно $R$-суперпаракомпактные отображения. В частности, решена задача сохранения $R$-паракомпактных (соответственно, сильно равномерно $R$-паракомпактных, равномерно $R$-суперпаракомпактных) пространств в сторону прообраза при равномерно $R$-паракомпактных (соответственно, сильно равномерно $R$-паракомпактных, равномерно $R$-суперпаракомпактных) отображениях.

Ключевые слова: равномерно непрерывное отображение, равномерно локально-конечное открытое покрытие, равномерно звездное конечное открытое покрытие, равномерно конечно-компонентное открытое покрытие.

\section{References}

1 Engelking, R. (1986). Obshchaia topologiia [General Topology]. Moscow [in Russian]. 
2 Musaev, D.K. (2004). Ravnomerno superparakompaktnye, vpolne parakompaktnye i silno parakompaktnye ravnomernye prostranstva [Uniformly superparacompact, quite paracompact and strongly paracompact uniform spaces]. Doklady Akademii nauk Respubliki Uzbekistan, 4, 3-9 [in Russian].

3 Rice, M.D. (1977). A note on uniform paracompactness. Proc. Amer. Math. Soc, 62(2), 359-362.

4 Kanetov, B.E. (2013). Nekotorye klassy ravnomernykh prostranstv i ravnomerno nepreryvnykh otobrazhenii [Some Classes of Uniform Spaces and Uniformly Continuous Mappings]. Bishkek [in Russian]. 